\title{
Participatory Action in Unraveling Farmers' Dependence towards Self-Sufficiency of Shallot Seeds in Pejok Village, Kedungadem Bojonegoro
}

\author{
Muhammad Nuril Huda', Nur Khoironi ${ }^{1}$, Khusnul Isma Nuriza ${ }^{2}$ \\ ${ }^{1}$ Islamic State University of Sunan Ampel Surabaya, ${ }^{2}$ STAI Al-Akbar Surabaya \\ E-mail: nuril.huda@uinsby.ac.id
}

\section{Article History: \\ Received: Jan 14th 2021 \\ Revised: March $11^{\text {th }} 2021$ \\ Accepted: May 30th 2021}

Keywords: dependence, farmers, shallot seeds.

\begin{abstract}
Pejok Village is one of the largest shallot producers in Bojonegoro Regency. However, farmers face a major obstacle; it is their dependence on the supply of shallot seeds from outside the region. This study aims to: 1) identify the problem of farmers' dependence on shallot seeds from outside the region; 2) find a solution to reduce the dependence of shallot farmers; and 3) take action in building farmers' independence towards self-sufficiency in shallot seeds. This study uses a Participatory Action Research (PAR) approach that emphasizes community involvement in identifying problems and coming up with solutions. There were two actions taken to solve the problems of the farmers, including 1) training on the cultivation of shallot seeds; 2) trial of shallot seed cultivation. This participatory action has succeeded in building the knowledge and abilities of farmers in Pejok Village in realizing independence in onion breeding.
\end{abstract}

\section{Introduction}

Pejok Village is one area on the edge of the South Kendeng mountain forest, precisely in Kedungadem District, Bojonegoro Regency, East Java Province. Geographically, Pejok Village is located on the southeast side of Bojonegoro Regency, with a distance of $42 \mathrm{Km}$ from the center of the Regency City and about $120 \mathrm{Km}$ from the Provincial City. With a population of 3,410 people, Pejok Village is divided into six hamlets: Kali Kunci Hamlet, Cerme Hamlet, Nglongok Hamlet, Sambong Gedhe Hamlet, Pejok Hamlet, and Bronjong Hamlet. The total area of Pejok Village is 451,899 ha, consisting of rice fields (200,260 ha), crooked land (22,260 ha), Tegal (101 ha), yard (41,994 ha), and GG land/governor ground (64 ha). ${ }^{1}$

Since the last decade, Pejok Village has become one of the producers of shallot commodities, especially centered in Dusun Bronjong. The potential of shallot farming in Pejok Village is indeed quite promising. With the assumption of planting $100 \mathrm{~kg}$ of seeds

\footnotetext{
${ }^{1}$ Dokumen Geografis dan Demografis Desa Pejok Kedungadem Bojonegoro Tahun 2020.
} 
on an area of $1,500 \mathrm{M}^{2}$, farmers can produce $1,500 \mathrm{~kg}$ of wet shallot. With the calculation of the selling price of the wet harvest of Rp. $10,000 / \mathrm{kg}$, at least farmers can earn Rp. 15,000,000,-. This income is then reduced by operational costs for one harvest season: purchase of seeds, labor wages, fertilizer and drug costs, and harvest costs. On average, farmers get a net profit of around 6.5 million rupiahs in one harvest season, or within 2 (two) months. ${ }^{2}$

Although the farmers in Pejok Village have enjoyed a fairly abundant production of shallots, it is not directly proportional to their income level. In addition, there is one fundamental problem faced by farmers, the lack of independence in terms of onion breeding. So far, farmers have always depended on supplies of shallot seeds from outside the region, especially from Nganjuk Regency. Some of the reasons that trigger patents to prefer shallot seeds from outside the region, among others (1) smaller size so that it can reach a wider area of land; (2) not easy to void if stored for a long time; and (3) do not rot easily when planted.

Based on the results of the FGD with the Technical Implementation Unit of the Kedungadem District Agriculture Office and onion farming practitioners, the condition of the seeds is hollow and susceptible to rot due to the high nitrogen content. Therefore, shallot seeds from agriculture in Pejok Village have relied more on rainwater, which has a reasonably high nitrogen content and the high nitrogen fertilizer composition factor used by farmers. From this, it appears that the cropping pattern is a determinant of the quality of the shallot crop yields, including if it will be used for seeds.

The circulation of capital expenditures for shallot farmers in Pejok Village for the supply of seeds from outside the region is fantastic. For example, if the average requirement of each farmer in one harvest season is three quintals $(300 \mathrm{Kg}$ ), multiplied by the number of farmers in Bronjong Hamlet by 300 families, then the need for shallot seeds reaches $9,000 \mathrm{Kg}$ (9 tons). With the calculation of the price of shallot seeds $\mathrm{Rp}$. $40,000 / \mathrm{Kg}$, then the capital turnover issued by shallot farmers from Bronjong Hamlet itself reaches Rp. 360,000,000,- in one harvest season. With this condition, of course, farmers will spend more energy, time, and operational costs when they cannot provide shallot seeds independently.

In addition to the quality of the seeds, the shallot seeds supply from outside the region is often exploited by the game of suppliers, which triggers higher prices. Moreover, because of financial limitations, farmers are forced to borrow business capital with a certain interest. The implication is that farmers' incomes tend to be significantly reduced because they have to cover production costs. For this reason, strategic steps are needed to help unravel the dependency problem of farmers towards self-sufficiency in shallot seeds.

2 Referring to the 2014 UIN Sunan Ampel Community Service Program (KKN) PAR Report in Pejok Village, Kedungadem District, Bojonegoro Regency and updated through FGD in February 2021.

ISSN: 2579-8375 (Print), ISSN: 2579-8391 (Online) | 31 


\section{Method}

This community assistance uses a Participatory Action Research (PAR) approach to study and carry out empowerment activities by involving community roles. PAR is a process of developing knowledge by integrating action and reflection, theory and practice, community participation, and providing solutions to problems that occur in the community. ${ }^{3}$ This mentoring activity is also referred to as the process of community organization. Brokensha and Hodge emphasized that "community organization was developed as a concept from the experience of evolving organizations and institutions to meet people's need and promote citizen participation."4

This action research tries to unravel the dependency problem of shallot farmers by taking the locus in Dusun Bronjong, Pejok Village, Kedungadem District, to find solutions to increase self-sufficiency in superior local shallot seeds. This action research is intended to: (1) identify the root causes of the dependence of the shallot farming community on seeds from outside the region; (2) planning a solution framework to reduce the dependence of shallot farmers on seeds from outside the region; and (3) carry out participatory actions towards self-sufficiency in shallot seeds in farming communities.

Action research does not start with a desire to change other people but starts with a change orientation. Therefore, the process of social change in this study also involves the roles of various parties, including farmers, Farmers Group Association (Gapoktan), youth farmers, religious/community leaders, Village Heads/Village Apparatus, Agriculture Service, practitioners of fertilizers and agricultural drugs, seed suppliers, and the Government of Bojonegoro Regency. In addition, each party has involvement in assisting the action research process: obtaining information, discussing partners, or assisting in community empowerment actions.

The mentoring strategy used refers to the PAR stages as a cycle, including (1) preliminary mapping; (2) building social relationships; (3) setting the research agenda for social change; (4) participatory mapping; (5) formulating the problem; (6) developing a movement strategy; (7) community organizing; (8) launching change action; (9) building community learning centers; (10) reflection; and (11) expanding the scale of movement and support. ${ }^{5}$ In summary, this community empowerment-based research cycle is known as KUPAR (to Know, to Understand, to Plan, to Action, to

3 Peter Reason and Hilary Bradbury, Action Research: Participative Inquiry and Practice (Los Angeles: Sage Publications, 2008), 4.

4 Isbandi Rukminto Adi, Intervensi Komunitas \& Pengembangan Masyarakat sebagai Upaya Pemberdayaan Masyarakat (Jakarta: PT. Rajawali Pres, 2013), 159.

5 Agus Afandi dkk, Modul Participatory Action Research untuk Pengorganisasian Masyarakat (Surabaya: Lembaga Pengabdian Kepada Masyarakat (LPM) IAIN Sunan Ampel, 2012), 79-82.

ISSN: 2579-8375 (Print), ISSN: 2579-8391 (Online) | 32 
Reflection): ${ }^{6}$

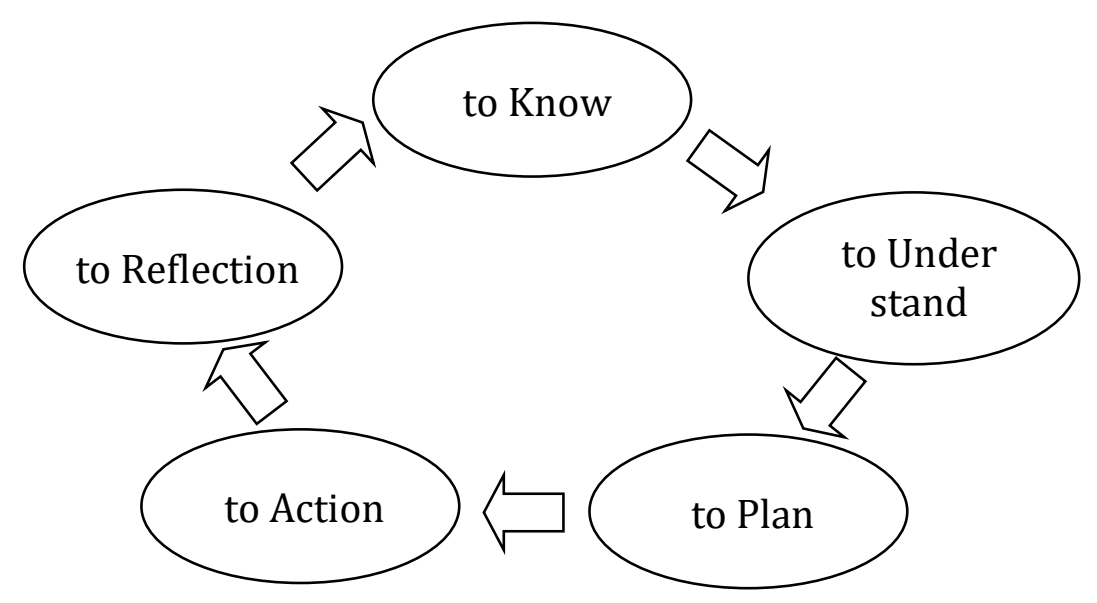

Figure 1. Partcipatory Action Research Cycle

The techniques used include mapping, transect, household survey, historical tracing, seasonal calendar, daily calendar, semi-structured interview, Venn diagram, flow chart, problem and expectation tree analysis.

Table. 1 Assistance Data Collection Techniques

\begin{tabular}{cll}
\hline No & \multicolumn{1}{c}{ Data Needs } & \multicolumn{1}{c}{ Technique } \\
\hline 1 & $\begin{array}{l}\text { Geographical, demographic, and historical } \\
\text { conditions of Pejok Village }\end{array}$ & $\begin{array}{l}\text { Mapping, transect, } \\
\text { historical tracing }\end{array}$ \\
\hline 2 & Onion farmer planting season pattern & $\begin{array}{l}\text { Seasonal Calendar } \\
\text { Diagram }\end{array}$ \\
\hline 3 & Income level of the community (farmers) & Household survey \\
\hline 4 & $\begin{array}{l}\text { Capital circulation during one harvest } \\
\text { season }\end{array}$ & Semi-structured interview \\
\hline 5 & $\begin{array}{l}\text { The flow of the involvement of the parties } \\
\text { in the shallot farming system }\end{array}$ & $\begin{array}{l}\text { Venn diagram, flow chart } \\
\text { problems faced and hopes of shallot } \\
\text { farmers }\end{array}$ \\
\hline
\end{tabular}

${ }^{6}$ Abdul Rahmat dan Mira Mirnawati, "Model Participation Action Research dalam Pemberdayaan Masyarakat, "AKSARA: Jurnal Ilmu Pendidikan Non Formal 6, no. 1 (2020): 66-67. 


\section{Results}

\section{Discovering the main problem of the Onion Farmer}

The series of community assistance processes begins with problem identification through mapping, interviews, and discussions with the community. Based on the initial mapping results, it was found the problem of dependence of shallot farmers on seeds from outside the region as shown below:

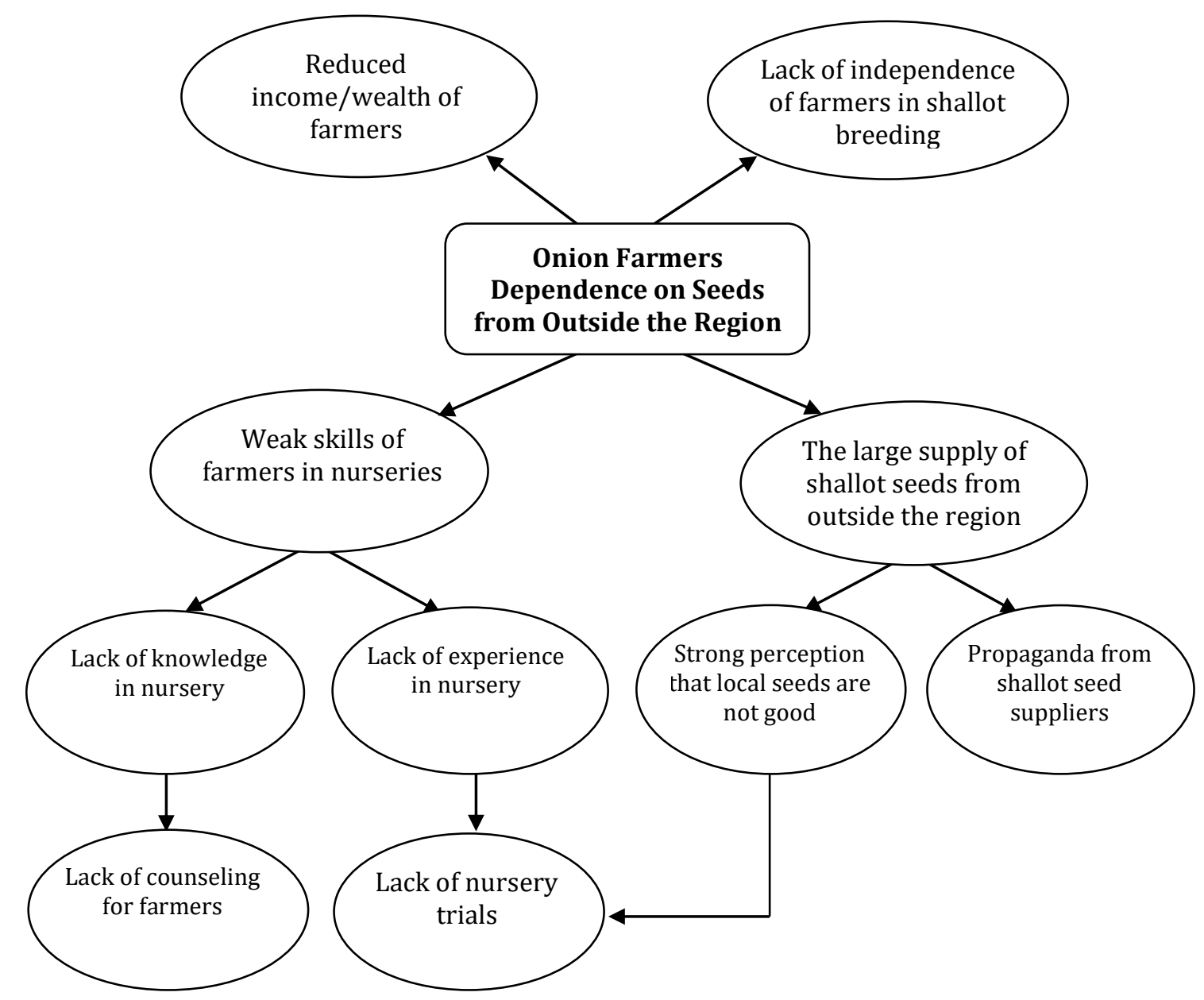

Figure 2. Analysis of the Dependence Problem Tree of Shallot Farmers

According to the figure above, two factors are causing the dependence of shallot farmers on seeds from outside the region: the weak expertise of farmers in a nursery and the incessant supply of shallot seeds from outside the region. The weak expertise of farmers in nurseries is due to the lack of knowledge and experience of farmers in nurseries. Meanwhile, the large supply of shallot seeds from outside the region is due to the strong perception of farmers that the quality of seeds from outside the region is better than local seeds and the propaganda factor from seed suppliers. 
The emergence of two causes of dependence on shallot farmers can be distinguished by internal and external factors. Internal factors come from within the farmers, such as farmers' lack of ability and experience in onion seeding. Meanwhile, external factors emerged from outside the farmers, such as the strong propaganda from seed suppliers. If this dependence continues, it will impact the weakness of the shallot farmers' independence in self-sufficiency in seeds and the reduced income and welfare of the farmers.

The number of farmers' income cannot be separated from how much operational costs are incurred during one harvest season. Based on the calculation of operational costs during one onion harvest season in Pejok Village, the need for purchasing seeds is relatively high. From the total operational costs incurred by farmers in one season, the percentage of the cost of purchasing seeds reaches $49.5 \%$; the rest is for land processing costs, planting, purchasing fertilizers and medicines, maintenance, and harvest costs. This has the potential to reduce the income or welfare of shallot farmers. The following table details the operational costs of planting shallots in Pejok Village during one harvest season:

Table. 2 Shallot Planting Cost

\begin{tabular}{|c|c|c|c|c|c|c|}
\hline No & $\begin{array}{c}\text { Description of operational } \\
\text { costs }\end{array}$ & Vol & Unit & $\begin{array}{c}\text { Price } \\
\text { unit }\end{array}$ & Amount & $\begin{array}{l}\text { Percen } \\
\text { tage }\end{array}$ \\
\hline 1 & Land Processing & 10 & People & 75.000 & 750.000 & $9,3 \%$ \\
\hline 2 & Shallot Seeds & 100 & $\mathrm{Kg}$ & 40.000 & 4.000 .000 & $49,5 \%$ \\
\hline 3 & Planting personnel & 6 & People & 75.000 & 450.000 & $5,5 \%$ \\
\hline 4 & $\begin{array}{l}\text { Fertilizer: } \\
\text { a. Phonska (50kg) } \\
\text { b. Urea }(50 \mathrm{~kg}) \\
\text { c. } \\
\text { NPK /mutiara }(1 \mathrm{Kg})\end{array}$ & $\begin{array}{l}2 \\
2 \\
1\end{array}$ & $\begin{array}{l}\mathrm{Kg} \\
\mathrm{Kg} \\
\mathrm{Kg}\end{array}$ & $\begin{array}{r}250.000 \\
350.000 \\
15.000 \\
\end{array}$ & $\begin{array}{r}500.000 \\
700.000 \\
15.000 \\
\end{array}$ & $15,5 \%$ \\
\hline 5 & $\begin{array}{l}\text { Agricultural Medicine: } \\
\text { a. Herbicide }(100 \mathrm{ml}) \\
\text { b. } \text { ZPT leaf(Gandasil) } \\
\text { c. Contact Fungisida }(2 \mathrm{Kg}) \\
\text { d. } \\
\end{array}$ & $\begin{array}{l}2 \\
2 \\
2 \\
2\end{array}$ & $\begin{array}{l}\text { Ltr } \\
\mathrm{Kg} \\
\mathrm{Kg} \\
\mathrm{Ltr}\end{array}$ & $\begin{array}{r}75.000 \\
30.000 \\
90.000 \\
150.000 \\
\end{array}$ & $\begin{array}{r}150.000 \\
60.000 \\
180.000 \\
300.000 \\
\end{array}$ & $8,5 \%$ \\
\hline 6 & Maintenance Personnel & 12 & People & 50.000 & 600.000 & $7,4 \%$ \\
\hline 7 & Harvest Cost & 5 & People & 75.000 & 375.000 & $5 \%$ \\
\hline \multicolumn{5}{|c|}{ Total } & 8.755 .000 & $100 \%$ \\
\hline
\end{tabular}

Identifying problems and impacts on the dependence of shallot farmers on seeds from outside the region show that there is a pattern of interaction and interrelationships between various parties. These interactions occur in the distribution of goods/services, mutually beneficial relationships, and coordination in various 
matters. The various parties involved in the interaction include seed producers, farmer groups associations, seed suppliers, distributors of agricultural fertilizers and drugs, village officials, youth farmers and UPTD Agriculture. The pattern of interaction between parties related to the dependence of shallot farmers in Pejok Village is as shown in the following flowchart:

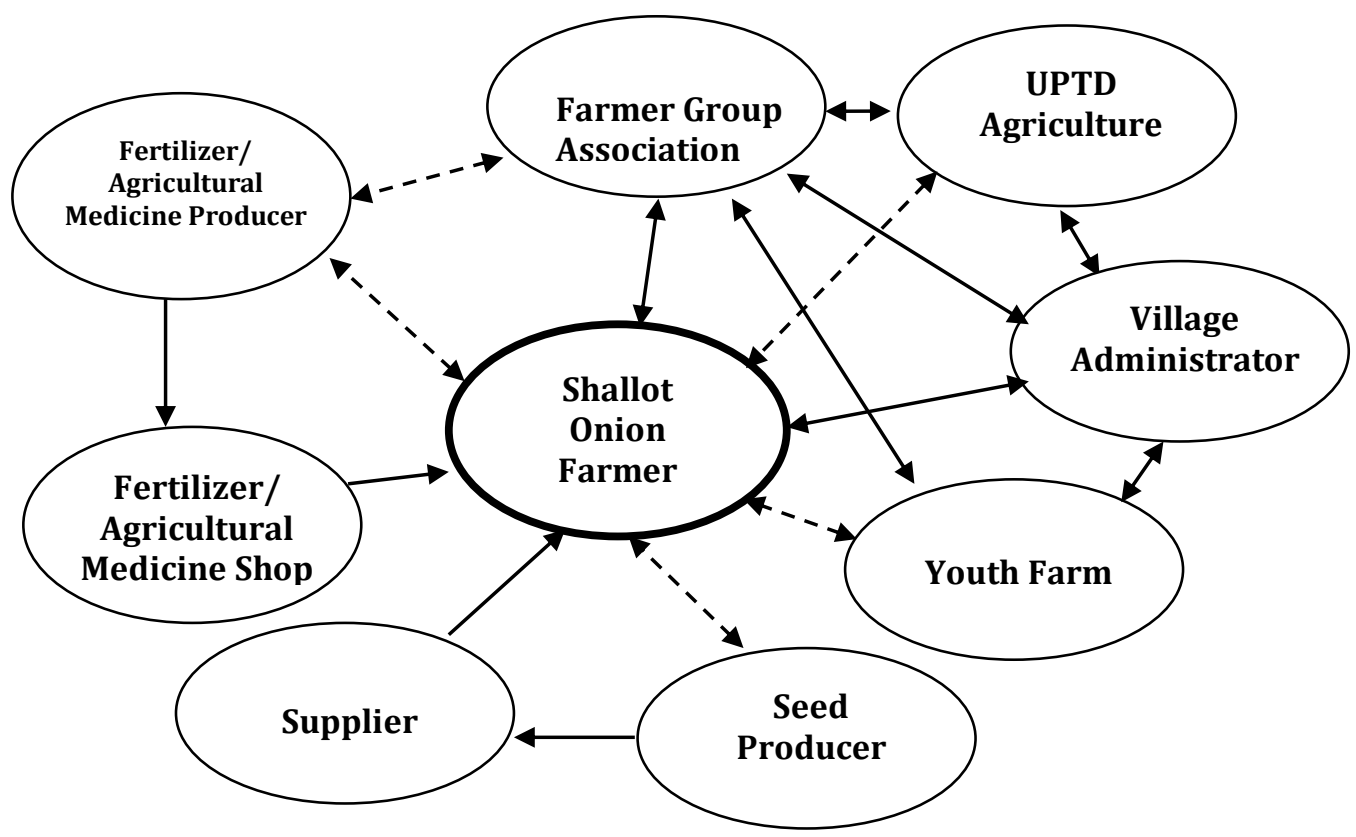

Information :

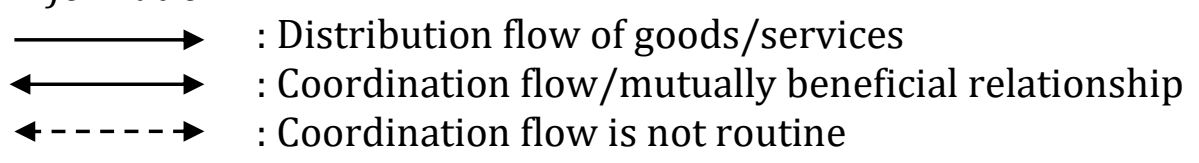

Figure 3. Pejok Village Shallot Farmer Interaction Flowchart

By looking at the nodes of these social groups, it can be identified which parties can be connected as partners for discussion and action in unraveling the dependence of shallot farmers. This participatory action requires changes in the social system in order to build understanding and cooperation between lines. In the concept of social change, action plans are part of the community organizing process by involving the structure as the target of change. This includes the involvement of social groups to sustain change through group roles, communication structures within groups, and group influence. ${ }^{7}$

${ }^{7}$ Nanang Martono, Sosiologi Perubahan Sosial; Perspektif Klasik, Modern, Posmodern dan Poskolonial (Jakarta: PT Raja Grafindo Persada, 2012), 251. 


\section{Participatory Action with Shallot Farmers}

The solution for solving the problems of shallot farmers in Pejok Village is inseparable from efforts to optimize the yield of the potential shallot commodity. Until now, the shallot commodity has been widely developed by the community and has good market opportunities. Moreover, this commodity is also a source of income and employment opportunities and is able to make a reasonably high contribution to regional economic development. ${ }^{8}$ The realization of farmers' independence in making seeds will indirectly encourage an increase in the yield of shallots in Pejok Village.

In addition to encouraging farmers' independence, participatory action is also oriented towards building an economic system in rural areas. The policy formulation process to support rural economic development includes several things, including (1) basic strategies for solving problems; (2) the achievement of the goal of solving the problem; (3) supporting policies; and (4) program-oriented policies. This is in accordance with the goal of PAR, which is not only to understand the problems facing the community but also to bring about change by actively involving them in the formulation of solutions. ${ }^{9}$

PAR activities in building collective community involvement are indeed quite complex. The process does not occur linearly but involves a socio-cultural, political, and power context that occurs asymmetrically. ${ }^{10}$ Several approaches are needed in community organizing according to the social situation. Rothman describes several approaches in the community intervention process, including local community development, social planning and policy, and social action.. ${ }^{11}$ In addition, it also requires certain strategies that must be considered by change actors. Several alternative social change strategies can be chosen, including facilitative strategies, reeducative strategies, persuasive strategies, power strategies, and violent versus non-violent strategies. ${ }^{12}$

In this participatory action, the researcher used a locality development approach with facilitative and reeducative strategies. The framework of the local community development approach in participatory action in the shallot farmer community in Pejok Village can be seen from the trend of the intervention model used and the condition of the assisted community. When carrying out the change process, one of them emphasizes the involvement of various groups of citizens to determine and solve their problems.

8Susanawati, "Identifikasi Risiko Rantai Pasok Bawang Merah di Kabupaten Nganjuk," AGRARIS: Journal of Agribusiness and Rural Development Research 3, no. 1 (2017): 15-16.

${ }^{9}$ Lai Fong Chiu, "Transformational Potential of Focus Group Practice in Participatory Action Research, Action Research 1, no. 2 (2003): 176.

${ }^{10}$ Susan Woelders and Tineke Abma, "Participatory Action Research to Enhance the Collective Involvement of Residents in Elderly Care: About Power, Dialogue and Understanding," Action Research 17, no. 4 (2019): 544.

${ }^{11}$ Rothman, Jack., et.all., Strategies of Community Intervention, Macro Practice. 5th edition (Itasca: FE Peacock Publishers Inc, 1995), 57.

${ }^{12}$ Nanang Martono, Sosiologi Perubahan Sosial..., 257-259. 
For the choice of a strategy used, the facilitative strategy acts so that the facilitator can provide various resources, information, and consultation facilities. This is conducted for the whole series of participatory actions by involving various parties who are seen as contributing to social organization and change. Meanwhile, the reeducative strategy refers to efforts to create change through structured programs and training for potential target groups to accept change directly or indirectly. This strategy is used to strengthen the capacity of the shallot farmer community in the form of training or counseling.

Based on the problem tree analysis as described above, it becomes a key point to develop a participatory action plan in solving the problems of shallot farmers in Pejok Village. Through the hope tree analysis technique, participatory action to build farmers' independence in producing shallot seeds in Pejok Village is projected into two activities: (1) providing extension or training on shallot seedlings for farmers; (2) conducting trials of shallot seedlings. Several stages were carried out to support the implementation of these two activities, ranging from Focus Group Discussions (FGD) to the development of communication networks and collaborations with various parties.

The shallot nursery training activity for farmers in Pejok Village is one form of action as a follow-up to the results of problem mapping. Based on the problem tree analysis results, it can be identified that the weak expertise of farmers in nurseries is due to their lack of knowledge about nurseries. Therefore, providing shallot nursery training for farmers in Pejok Village is expected to increase their ability to produce superior shallot seedlings. Furthermore, improving farmers' breeding ability will encourage the creation of independence and reduce their dependence on shallot seeds from outside the region.
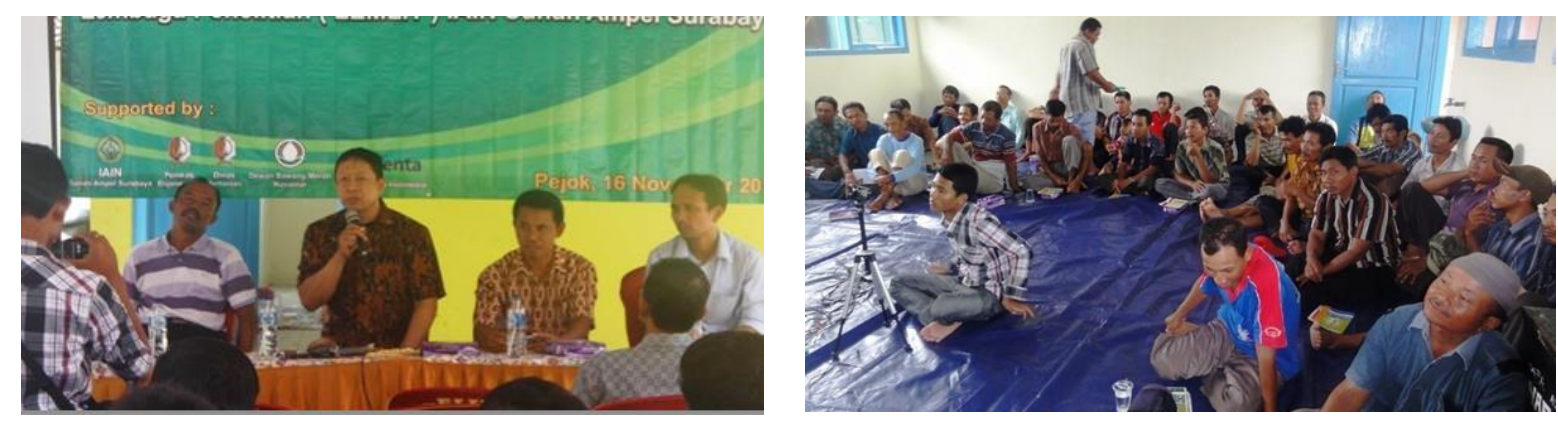

Figure 4. Shallot Nursery Training in Pejok Village

After the shallot nursery training activity, it was followed by a nursery trial, which was conducted on the land of one of the farmers in Bronjong Hamlet. This activity is a strategic step to improve the experience of farmers in making superior shallot seeds. With increasing experience, it will stimulate the expertise of farmers in making shallot seeds. Referring to several records of the training results that have been carried 
out previously, pilot activities need to consider several things: (1) selection of trial land with different soil characteristics to see differences in seedling results; (2) seed selection and treatment before planting; (3) regulation of the composition and frequency of application of fertilizers and agricultural drugs; and (4) setting of postharvest seeds for the fermentation process.
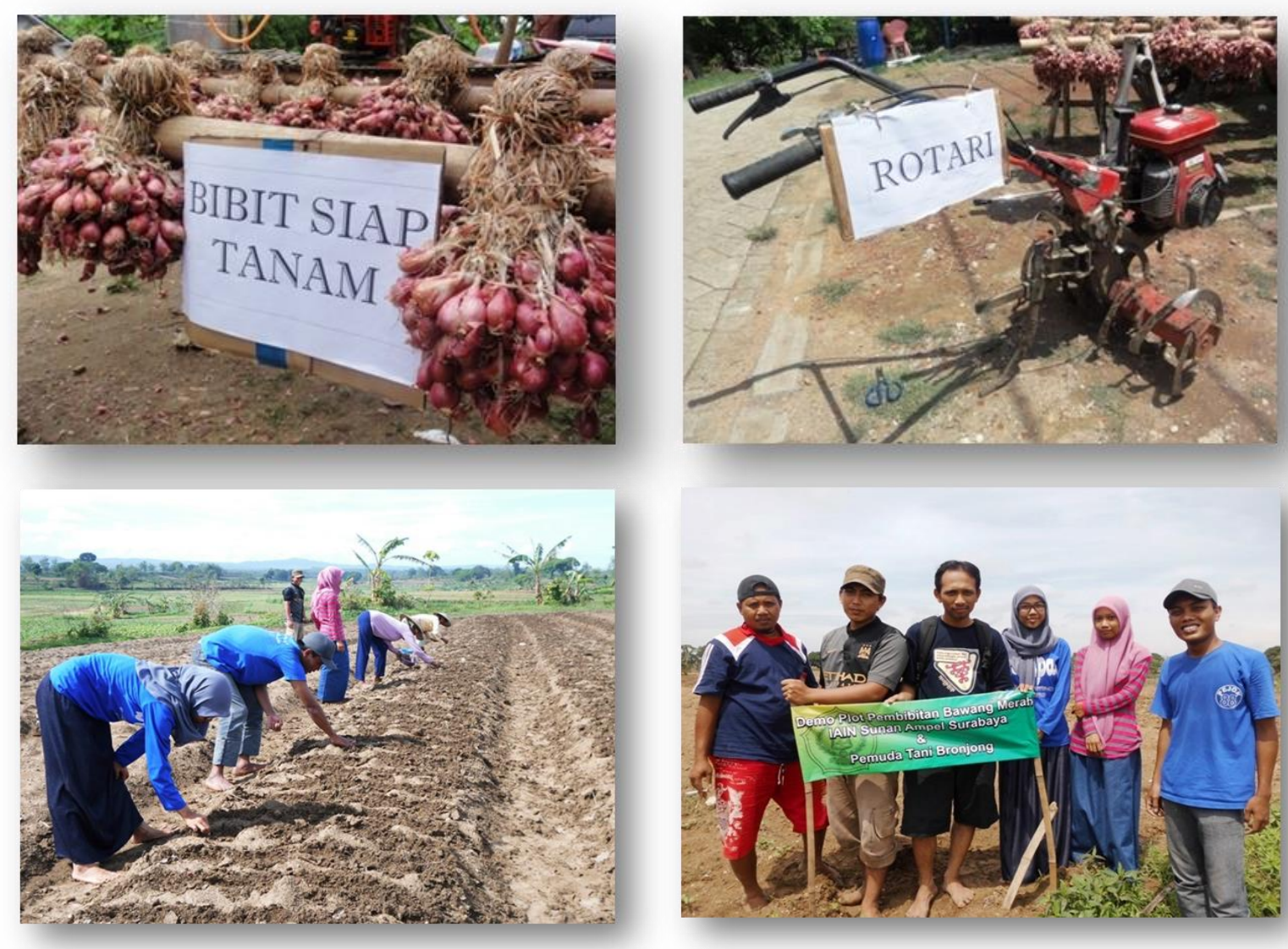

Figure 5. Shallot Nursery Trial in Pejok Village

On a small scale, the trial process for shallot nurseries has shown quite good results, from the stage of land preparation, seed preparation to storage and fermentation processes to be used as seeds for the next growing season. This stage needs to be carried out continuously and replicated in a wider scope. Of course, it must involve support from various parties to continue to conduct nursery trials until indeed optimal results are obtained. Cooperation between farmers, village governments, NGOs, agricultural practitioners, universities, and local governments must continue to be built to create synergy in realizing self-sufficiency in shallot seeds in Pejok Village. 


\section{Discussion}

Based on the exposure of facts related to the problem of dependence of shallot farmers in Pejok Village on seeds from outside the region, it shows the community's powerlessness for the conditions they experience. Behind the feeling of comfort and acceptance of what they have experienced so far, the community has not been able to unravel the root of the dependency problem they face. This is because there is no alternative perspective as a solution, so the problem of dependence on shallot seeds from outside the area is faced by farmers with a resigned attitude.

Dependency has an important influence on the sustainability of performance, although this influence is often not clearly and definitely found. ${ }^{13}$ When a community is dependent on certain goods or services, it will also affect the sustainability of their activities and productivity. Within the framework of resource dependence theory, the approach to unraveling this problem can be viewed from the perspective of the concepts of power (power) and dependence (dependence). As Emerson (1962) said, the basis of power is dependence. A depends on B if A has goals and needs that can be met by $B$. These two variables contain interrelated dimensions of interpersonal or social relationships. Thus, dependence on a person or group will be related to the other party's power.

This dependency postulate is also in line with the view of Stephen P. Robbins, that:

"The greater B's dependence on A, the more power A has over B. If A has what B needs and only $A$ controls, then A makes $B$ dependent on A. Hence A gains power over $B$ ". ${ }^{14}$

The postulate above can be understood that if one party is dependent on another party, it will trigger the emergence of power on the other party. The greater the party's dependence on another party, the greater the power of the other party on him. In terms of unraveling the dependency problem of shallot farmers in Pejok Village, it can also be identified with this theoretical framework of analysis. If the dependence of shallot farmers on seeds from outside the region is greater, the greater the power that seed suppliers have over shallot farmers in Pejok Village, especially in supplying goods and controlling prices.

Several things cause the emergence of dependence of a person or group on another person or group. Mintzberg identifies three factors for the emergence of dependence: the existing resources are important, scarce, and cannot be replaced.

\footnotetext{
${ }^{13}$ Sabine Wagenhals, Wendy Garner, Les Duckers, and Katja Kuhn, "Sustainability Index With Integrated Indicator Dependencies," Business, Management and Education 12, no. 1 (2014): 16.

${ }^{14}$ Stephen P. Robbins, Organizational Behavior: Concepts, Controversies, Applications (New Jersey: Prentice Hall, Inc, 1996); Alih Bahasa: Hadyana Pujaatmaka, Perilaku Organisasi (Jakarta: Prenhallindo, 1996), 88.
} 


\section{Important Meaning}

If no one wants what someone has, then dependence on that person will not occur. Therefore, to create dependence, some parties try to manage and control things that are considered important to others to be used as capital for transactions of interest. Something that has an important meaning will be a motivating factor for individuals or groups to get it. Regarding the dependency problem of shallot farmers in Pejok Village, it also appears that there is an important value of shallot seeds from outside the region, which farmers still expect. The shallot seeds' value or importance from outside the region is in line with the level of need, under certain conditions, between what is needed by farmers and what is provided by seed suppliers outside the region. The strong perception about the higher quality of seeds from outside the region compared to local seeds increases the importance of seeds from outside the region for farmers.

\section{Scarcity}

As stated earlier, if something is large in number, its possession will increase the degree of power. Therefore, resources must be seen as scarce in order to create dependencies. This can help explain how an individual or group's position on resource scarcity can lead to dependency and power. The aspect of scarcity is also a factor that influences the dependence of shallot farmers in Pejok Village on seeds from outside the region. This is due to the scarcity of quality local shallot seeds compared to seeds from outside the region. Apart from the various obstacles behind the inability of farmers to provide seeds independently, what is certain is that the scarcity factor can be seen as one of the factors that trigger dependence.

\section{Irreplaceable condition}

The fewer substitutes available for a resource, the more power the controller has over that resource. The existence of seeds from outside the region has not been replaced by the supply of local shallot seeds. This irreplaceable situation is also caused by the systematic role of seed suppliers in circulating the supply of seeds from outside the region and determining prices. The incessant propaganda from suppliers has further strengthened the farmers' perception that shallot seeds outside the region are better than local seeds. In the absence of other options, this situation makes shallot seeds from outside the region still irreplaceable.

Dependence on something is influenced by how many alternatives are available and are perceived as having important value to meet needs or wants. The more alternatives or choices a person has, the less dependent he is on other parties. The implication is that this party will have less and less power. The relationship between 
power, dependence, and alternatives can be illustrated as follows:

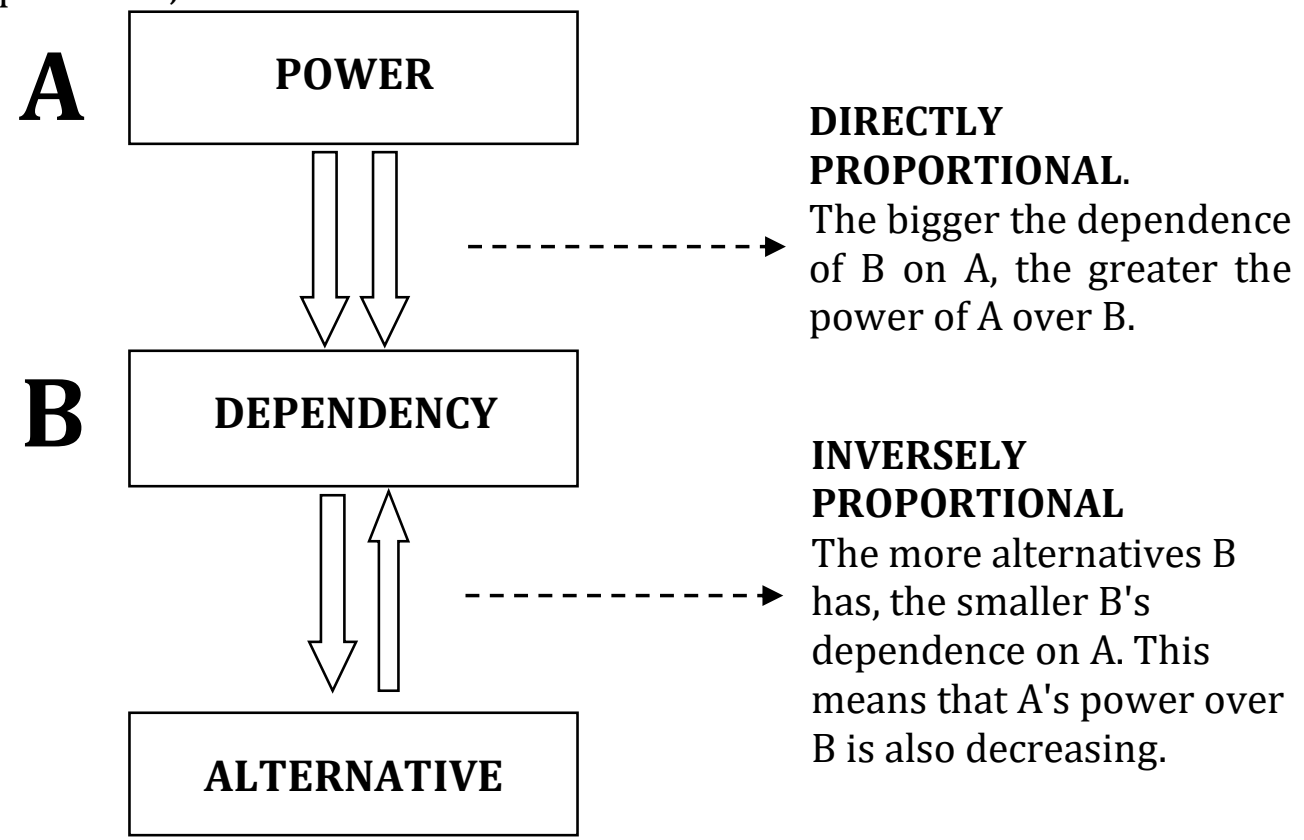

Figure 6. The Relation Between Power, Dependence, and Alternative

In this context, the dependence of shallot farmers in Pejok Village on seeds outside the region will decrease when the shallot farming community has alternatives or other options in providing seeds. Therefore, one crucial step to reduce this dependence is to increase the availability of local shallot seeds. But, of course, this must be accompanied by an increase in the ability of farmers to produce seeds independently. When the choices in the supply of shallot seeds can be fulfilled independently by the local community, there will be no absolute power from suppliers of shallot seeds from outside the region.

According to the concept of structural-functional theory, these conditions reflect society's facts and dynamics, which consist of interrelated and interdependent parts. As Stephen K. Sanderson views, society is a complex system that consists of interconnected parts, interdependent, and each part influences the other parts. Every part of society exists because that part has an essential function in maintaining the existence and stability of society in maintaining the existence of society as a whole. ${ }^{15}$

The interrelated and interdependent parts can be seen from the pattern of transactional interactions between shallot farmers in Pejok Village and seed suppliers. The need for shallot seeds that have not been provided independently by the farmers directs them to interact with other parties, thus triggering dependence. Furthermore, the structure and function of each group place themselves in different needs and interests, so that the dominance of resources in one group (shallot seed suppliers) has implications for the emergence of dependence on other groups, in this case, the shallot

${ }^{15}$ Dewi Wulan Sari, Sosiologi: Konsep dan Teori (Bandung: PT Refika Aditama, 2009), 174. 
farmers in Pejok Village.

Provision of alternatives to reduce dependence on shallot seeds from certain areas (especially Nganjuk) is not made by looking for alternative supplies of seeds from other areas. But by building independence in the cultivation of local shallot seedlings independently by the farming community in Pejok Village. This dependence will certainly be reduced gradually when the farming community can produce their own seeds, not by looking for or switching to different seed suppliers.

Quoting the opinion of Dos Santos, who expands on Gunder Frank's argument in examining the problem of dependency, he stated that: "....dependence is not entirely the external factor which it is often believed to be". According to him, dependence is not merely something that comes from external factors, as is always considered. This perspective can indicate that dependency problems do not have to arise or involve factors outside the individual or group. When individuals or groups can fulfill certain resources, dependence on external factors will not occur.

\section{Conclusion}

The main problem of dependence of shallot farmers in Pejok Village on seeds from outside the region is at least due to two things: (1) the weak ability of the farmers in breeding shallots due to their lack of knowledge and experience; (2) the large supply of shallot seeds from outside the region is due to the strong perception of farmers that the quality of seeds from outside the region is better than local seeds, in addition to the propaganda factor from seed suppliers. Based on these problems, the form of participatory action carried out includes two things, providing training on shallot nurseries and conducting trials of shallot nurseries with the farming community.

This series of participatory action research processes have succeeded in generating mutual understanding and increasing the ability of shallot farmers to realize independence in making local shallot seeds. Participation and cooperation with various parties in realizing self-sufficiency in shallot seeds have also been established, both with the farming community in Pejok Village, the government, and NGOs who have been concerned about the cultivation of shallots. The understanding and ability of farmers in shallot seedling need to be continuously supported and closely monitored to maintain the sustainability of the shallot yield improvement program in Pejok Village.

The dependency postulate that can be contextualized in observing the problems of shallot farmers in Pejok Village is: "The greater the dependence of farmers in Pejok Village on producers or suppliers of shallot seeds from outside the region, the greater the power of shallot seed suppliers over the farmers. The more alternatives that farmers have in providing shallot seeds independently, the less dependence they will have on suppliers of shallot seeds from outside the region." For this reason, it is necessary to 
take participatory action by involving various parties to build the independence of the farmers in providing seeds so that the dependence of shallot farmers in Pejok Village can be further broken down.

\section{Acknowledgement}

Sincere gratitude to all those who have assisted in implementing this Participatory Action Research, especially starting from the KKN program for students at UIN Sunan Ampel Surabaya in Pejok Village since 2013. The other gratitude to the Pejok Village Head and his staff, Pejok Village Farmers Group, Pejok Village Farmers Youth, community leaders, the National Shallots Council, and the Bojonegoro Regency Agriculture Service that have been happy to share knowledge, experiences, and shared values.

\section{Reference}

Adi, Isbandi Rukminto. Intervensi Komunitas \& Pengembangan Masyarakat sebagai Upaya Pemberdayaan Masyarakat. Jakarta: PT. Rajawali Pres, 2013.

Afandi, Agus dkk. Modul Participatory Action Research untuk Pengorganisasian Masyarakat. Surabaya: Lembaga Pengabdian Kepada Masyarakat (LPM) IAIN Sunan Ampel, 2012.

Arief, Sritua dan Adi Sasono. Indonesia: Ketergantungan dan Keterbelakangan. Jakarta: Mizan, 2013.

Borgatti, Stephen P, Dependency Theory, http://www.analytictech.com/mb021/ dependen.htm

Chiu, Lai Fong. "Transformational Potential of Focus Group Practice in Participatory Action Research, Action Research 1, no. 2 (2003): 165-183.

Dokumen Geografis dan Demografis Desa Pejok Kecamatan Kedungadem Kabupeten Bojonegoro Tahun 2020.

Jack, Rothman, et.all. Strategies of Community Intervention, Macro Practice. 5th edition. Itasca: FE Peacock Publishers Inc, 1995.

Laporan KKN PAR UIN Sunan Ampel Tahun 2014 di Desa Pejok Kecamatan Kedungadem Kabupaten Bojonegoro.

Martono, Nanang. Sosiologi Perubahan Sosial; Perspektif Klasik, Modern, Posmodern dan Poskolonial. Jakarta: PT Raja Grafindo Persada, 2012.

Nogroho, Iwan \& Rokhim Dahuri. Pembangunan Wilayah: Perspektif Ekonomi, Sosial dan Lingkungan. Jakarta: LP3ES, 2012. 
Rahmat, Abdul dan Mira Mirnawati. "Model Participation Action Research dalam Pemberdayaan Masyarakat." AKSARA: Jurnal Ilmu Pendidikan Non Formal 6, no. 1 (2020): 62-71.

Reason, Peter and Hilary Bradbury. Action Research: Participative Inquiry and Practice. Los Angeles: Sage Publications, 2008.

Robbins, Stephen P. Organizational Behavior: Concepts, Controversies, Applications. New Jersey: Prentice Hall, Inc, 1996; Alih Bahasa: Hadyana Pujaatmaka, Perilaku Organisasi. Jakarta: Prenhallindo, 1996.

Sari, Dewi Wulan. Sosiologi: Konsep dan Teori. Bandung: PT Refika Aditama, 2009.

Susan Woelders and Tineke Abma. "Participatory Action Research to Enhance the Collective Involvement of Residents in Elderly Care: About Power, Dialogue and Understanding," Action Research 17, no. 4 (2019): 528-548.

Susanawati, "Identifikasi Risiko Rantai Pasok Bawang Merah di Kabupaten Nganjuk," AGRARIS: Journal of Agribusiness and Rural Development Research 3, no. 1 (2017): $15-22$.

Wagenhals, Wendy Garner, Les Duckers, and Katja Kuhn, "Sustainability Index With Integrated Indicator Dependencies," Business, Management and Education 12, no. 1 (2014): 15-29. 